\title{
Antipsychotic Drugs Inhibit the Human Corticotropin-Releasing-Hormone Gene Promoter Activity in Neuro-2A Cells - an Involvement of Protein Kinases
}

\author{
Agnieszka Basta-Kaim*,', Bogusława Budziszewska', Lucylla Jaworska-Feil', Magdalena Tetich', \\ Marta Kubera', Monika Leśkiewicz', Magdalena Otczyk' and Władysław Lasoń' \\ 'Laboratory of Immunoendocrinology, Department of Experimental Neuroendocrinology, Institute of Pharmacology, Polish Academy of Sciences, \\ Kraków, Poland
}

\begin{abstract}
Antipsychotic drugs can regulate transcription of some genes, including those involved in regulation of hypothalamic-pituitary-adrenal (HPA) axis, whose activity is frequently disturbed in schizophrenic patients. However, molecular mechanism of antipsychotic drug action on the corticotropin-releasing hormone $(\mathrm{CRH})$ gene activity has not been investigated so far. This study was undertaken to examine the influence of conventional and atypical antipsychotic drugs on the CRH gene promoter activity in differentiated Neuro-2A cell cultures stably transfected with a human $\mathrm{CRH}$ promoter fragment linked to the chloramphenicol acetyltransferase (CAT) reporter gene. It has been found that chlorpromazine $(0.1-5.0 \mu \mathrm{M})$, haloperidol $(0.5-5.0 \mu \mathrm{M})$, clozapine ( $1.0-5.0 \mu \mathrm{M})$, thioridazine $(1.0-5.0 \mu \mathrm{M})$, promazine (5.0 and $10 \mu \mathrm{M})$, risperidone $(5.0$ and $10.0 \mu \mathrm{M}$ ), and raclopride (only at the highest used concentrations, ie 30 and $100 \mu \mathrm{M}$ ) present in culture medium for 5 days inhibited the $\mathrm{CRH}-\mathrm{CAT}$ activity. Sulpiride and remoxipride had no effect. Since CRH gene activity is most potently enhanced by cAMP/protein kinase A pathway, the effect of antipsychotics on the forskolin-induced CRH-CAT activity was

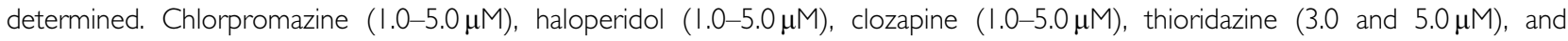
raclopride $(30$ and $100 \mu \mathrm{M})$, but not promazine, sulpiride, risperidone, and remoxipride, inhibited the forskolin-stimulated $\mathrm{CRH}$ gene promoter activity. A possible involvement of protein kinases in chlorpromazine and clozapine inhibitory action on $\mathrm{CRH}$ activity was also investigated. It was found that wortmannin $(0.01$ and $0.02 \mu \mathrm{M})$, an inhibitor of phosphatidylinositol 3-kinase (PI3-K), significantly attenuated the inhibitory effect of chlorpromazine and clozapine on $\mathrm{CRH}$ gene promoter activity. In line with these results, a Western blot study showed that these drugs increased phospho-Ser-473 Akt level, had no effect on total Akt, and decreased glycogen synthase kinase- $3 \beta$ level. Additionally, we found that clozapine decreased protein kinase $C$ (PKC) level and that its action on CRH activity was attenuated by PKC activator (TPA, $0.1 \mu \mathrm{M}$ ). The obtained results indicate that inhibition of $\mathrm{CRH}$ gene promoter activity by some antipsychotic drugs may be a molecular mechanism responsible for their inhibitory action on HPA axis activity. Clozapine and chlorpromazine action on CRH activity operates mainly through activation of the PI3-K/Akt pathway. Moreover, PKC-mediated pathway seems to be involved in clozapine action on $\mathrm{CRH}$ gene activity.

Neuropsychopharmacology (2006) 31, 853-865. doi:I0. I038/sj.npp. I 3009I I; published online 5 October 2005
\end{abstract}

Keywords: antipsychotic drugs; human CRH gene; differentiated Neuro-2A cells; forskolin; phosphatidylinositol 3-kinase/Akt pathway; protein kinase C

\section{INTRODUCTION}

Recently, it has been found that the dysregulation of the hypothalamic-pituitary-adrenal (HPA) axis occurs not only in the patients suffering from depression but also in schizophrenic disorders. Clinical studies have shown that some patients with schizophrenia have an increased

\footnotetext{
*Correspondence: Dr A Basta-Kaim, Department of Experimental Neuroendocrinology, Institute of Pharmacology, Polish Academy of Sciences, 12 Smętna Street, 31-343 Kraków, PL, Poland, Tel: +48 12 6623 273, Fax: + 48126374 500, E-mail: basta@if-pan.krakow.pl Received I 5 April 2005; revised 29 July 2005; accepted 2 August 2005 Online publication: 31 August 2005 at http://www.acnp.org/citations/ Npp083 I05050253/default.pdf
}

concentration of cortisol in plasma and/or increased release of cortisol after pretreatment with dexamethasone or dexamethasone with corticotropin-releasing hormone (CRH) (Lammers et al, 1995; Ryan et al, 2004; Tandon et al, 1991). Moreover, an association between postdexamethasone cortisol level and negative symptoms of schizophrenia was found (Newcomer et al, 1991). Diminished negative feedback regulation of the HPA axis activity in schizophrenia has been demonstrated also by a postmortem study, which showed a decreased level of glucocorticoid receptors (GR) mRNA in the hippocampus, frontal cortex, and temporal cortex (Webster et al, 2002). The decrease in GR levels in brain structures involved in a feedback inhibition mechanism, that is, inhibition of CRH 
synthesis and secretion from the hypothalamus, may cause HPA hyperactivity. Furthermore, it has been shown that high levels of glucocorticoids can induce psychosis in humans (Bloch et al, 1994; Ling et al, 1981), and enhance extracellular concentrations of dopamine and dopaminedependent behaviors in animals (Marinelli et al, 1994, 1997; Piazza et al, 1996). Besides exacerbation of dopaminergic system activity, glucocorticoids are known to enhance neurodegenerative processes, which along with changes in monoamine systems are likely responsible for the development of schizophrenia (McEwen and Magarinos, 2001).

Some papers suggest that HPA axis dysregulation in schizophrenia is a result of hypersecretion of $\mathrm{CRH}$ and could be generated by a monoamine neurotransmitter disturbance, altered expression or activity of GR in the brain, or an increased cytokine activity (Altamura et al, 1999; Meltzer, 1995; Webster et al, 2002). CRH is a primary regulator of the stress response. Apart from stimulating ACTH secretion, this peptide exerts many behavioral and autonomic effects, which coordinate a variety of responses associated with stress. CRH influenced central serotoninergic and catecholaminergic activities, for example, it increased dopamine synthesis and dopamine-induced behavior in experimental animals (Austin et al, 1997). CRH hypersecretion in depression and anxiety disorders and anxiogenic effect of $\mathrm{CRH}$ is well documented, but data concerning the role of this peptide in schizophrenia are limited. Nevertheless, CRH concentrations have been found to be elevated in schizophrenic patients after withdrawal from haloperidol treatment, and a tendency to the increase in the level of this peptide was observed in patients who relapsed (Forman et al, 1994). The relationship between $\mathrm{CRH}$ and schizophrenia has been demonstrated also in experimental animals. Chronically increased CRH level in transgenic mice overexpressing $\mathrm{CRH}$ is associated with sensorimotor gating deficits (prepulse-induced inhibition of acoustic startle response), which is a behavioral disturbance typical of schizophrenia (Dirks et al, 2002).

It has been shown that the altered HPA axis activity is usually corrected during a clinically effective therapy with antipsychotic drugs (Lammers et al, 1995; Tandon et al, 1991; Wik et al, 1986). Also, in the transgenic mice overexpressing $\mathrm{CRH}$, some antipsychotic drugs alleviated sensorimotor gating deficits (Dirks et al, 2002). However, there are only few data concerning the intracellular mechanism of modulatory effects of antipsychotics on HPA axis activity and the density or function of GR. Previously, we have found that some antipsychotics inhibit the GR-mediated gene transcription (Basta-Kaim et al, 2002). A purpose of the present study was to find out if antipsychotic drugs, which are known to affect the function of GR and neurotransmitters as well as activity of various protein kinases, can also modulate $\mathrm{CRH}$ gene transcription.

We examined the effect of several antipsychotic drugs belonging to various groups (with regard to their chemical structure, affinity for dopamine $\mathrm{D}_{2^{-}}$, serotonin $5-\mathrm{HT}_{2^{-}}$, $\sigma$ - and other membrane receptors, clinical efficacy, and side-effects), that is, chlorpromazine, thioridazine, perazine, haloperidol, sulpiride, raclopride, remoxipride, risperidone, and clozapine on the $\mathrm{CRH}$ gene promoter activity in vitro. To this end, we employed the differentiated Neuro-2A cell culture stably transfected with a human CRH promoter fragment linked to the chloramphenicol acetyltransferase (CAT) reporter gene (Budziszewska et al, 2002, 2004). This cell line displays a neuron-like phenotype both morphologically and neurochemically (Klebe and Ruddle, 1969). Neuronal differentiation in vitro is accompanied by morphological alterations, and elevates levels of neurotransmitters: serotonin, dopamine, and amino acids (Chatterjee et al, 1992). Furthermore, differentiated Neuro-2A cells are more sensitive than undifferentiated ones to psychotropic (antidepressant) drug action (Budziszewska et al, 2004).

Since functional cAMP-responsive element (CRE) sequence is present in the CRH gene promoter and activated by cAMP/protein kinase A (PKA)-mediated pathway - phosphoCRE-binding protein (CREB) is the main transcription factor involved in $\mathrm{CRH}$ gene regulation (Guardiola-Diaz et al, 1994; Spengler et al, 1992), the effect of antipsychotic drugs on forskolin-induced $\mathrm{CRH}$ gene promoter activity was also determined.

In the next part of the present study, the mechanism of chlorpromazine and clozapine action on CRH gene activity was investigated in greater detail. Specifically, an involvement of some enzymes, which are known to be changed in schizophrenia and are affected by antipsychotic drugs, that is, $\mathrm{PKA}$, protein kinase $\mathrm{C}(\mathrm{PKC})$, protein kinase $\mathrm{B}(\mathrm{PKB}$; $\mathrm{Akt})$, glycogen synthase kinase-3 (GSK-3), $\mathrm{Ca}^{2+} /$ calmodulin-dependent protein kinase (CaMK), and mitogen-activated protein kinase (MAPK), in the inhibitory action of chlorpromazine and clozapine on $\mathrm{CRH}$ gene promoter activity was determined (Dwivedi and Pandey, 1999; Dwivedi et al, 2002; Lu et al, 2004; Ninan et al, 2003; Yang et al, 2004). We chose for this study chlorpromazine, a classical antipsychotic drug and a atypical antipsychotic clozapine, because in the first part of study they showed the most potent inhibitory effects on the $\mathrm{CRH}$ gene activity.

Furthermore, since some antipsychotic drugs used at high concentrations have been shown to induce cell death in some neuronal cell lines (Post et al, 1998), their effects on Neuro-2A cell viability were also evaluated.

\section{MATERIALS AND METHODS}

\section{Cell Culture Conditions}

Neuro-2A (mouse neuroblastoma) cells, obtained from the American Type Culture Corporation (ATCC), were cultured in Dulbecco's modified Eagle's medium (Gibco BRL) supplemented with $10 \%$ fetal bovine serum (Gibco BRL), $50 \mathrm{U} / \mathrm{ml}$ of penicillin and $50 \mu \mathrm{g} / \mathrm{ml}$ of streptomycin (Sigma Co.), in an atmosphere composed of $5 \% \quad \mathrm{CO}_{2} / 95 \% \quad \mathrm{O}_{2}$ at $37^{\circ} \mathrm{C}$. Stably transfected cells were cultured in medium with zeocin $(150 \mu \mathrm{g} / \mathrm{ml}$; Symbios), instead of penicillin and streptomycin. For in vitro differentiation, the cells were grown for 3 days before the experiment in medium containing $1 \%$ serum.

\section{Plasmid Construction and Cell Transfection}

Details of hCRH-CAT plasmid syntheses were described previously (Budziszewska et al, 2002, 2004). Human DNA was isolated from blood using Blood DNA Prep Kit (A\&A Biotechnology, Poland). Based on the known human 
CRH gene promoter sequence (GenBank Accession No. AF48855), the specific primers from the region -663 to $+124 \mathrm{bp}$ were synthesized for PCR amplification. The amplification product was analyzed by electrophoresis on $1 \%$ agarose gels stained with ethidium bromide. Specific, approximately $800 \mathrm{bp}$ long, PCR product was obtained $(0.2 \mu \mathrm{g})$, which was purified using Clean-Up Kit (A\&A Biotechnology, Poland), and digested with BglII and KpnI, and then isolated from an agarose gel band using Gel-Out Kit (A\&A Biotechnology, Poland). The purified fragment was ligated into pSecTag2A (Invitrogen, USA) BglII-KpnI sites. Escherichia coli TOP10F' cells (Invitrogen, USA) were transformed with the ligation mixture, and 12 colonies were assayed for the presence of $\mathrm{CRH}$ promoter-encoding gene by PCR amplification and restriction analysis. Four independent clones with $\mathrm{CRH}$ promoter were selected, sequenced, and compared to the known DNA sequence. After sequencing, one plasmid was selected, named hCRH, and used for the next construct. The gene encoding CAT was amplified using the pACYC184 plasmid as a source of DNA-containing CAT gene. Specific PCR product (666 bp) was obtained, purified, and digested with BamHI and XhoI, and ligated into pCRH BamHI-XhoI plasmid sites. The obtained hCRH-CAT plasmid was analyzed by restriction digestion and sequencing.

The cells at $50-60 \%$ confluence were transfected with hCRH-CAT plasmid using LipofectAMINE reagent (Invitrogen, USA) according to the supplier's recommendation as described previously (Budziszewska et al, 2002, 2004). As pSecTag2A vector contains zeocin-resistant gene, at $72 \mathrm{~h}$ after transfection, the cells were passaged $(1: 6)$ to the selective medium with $600 \mu \mathrm{g} / \mathrm{ml}$ of zeocin (Invitrogen, USA). Before transfection the dose-response assays were performed, which showed that $300 \mu \mathrm{g} / \mathrm{ml}$ of zeocin was the lowest concentration that killed all, not-transfected Neuro$2 \mathrm{~A}$ cells. At 3-4 weeks after transfection, the zeocinresistant colonies were selected, cultured in the medium with zeocin $(150 \mu \mathrm{g} / \mathrm{ml})$, and assayed for reporter gene activity.

Neuro-2A cell line transfected with the plasmid that contained human cytomegalovirus (hCMV) instead of hCRH promoter was used as the control for antipsychotic drug action.

\section{Drug Treatments}

The influence of antipsychotic drugs on the basal and forskolin-induced $\mathrm{CRH}$ gene promoter activity in stably transfected differentiated Neuro-2A cells was determined. The cells were cultured in the presence of relevant vehicle, chlorpromazine hydrochloride (Sigma, St Louis, USA), clozapine (Polfa, Warszawa, Poland), haloperidol (RBI, NATICK, USA), sulpiride (Sigma, St Louis, USA), raclopride tartrate (Astra, Sodertalje, Sweden), remoxipride hydrochloride (Astra), risperidone (Janssen-Pharmaceutica, Beerse, Belgium), promazine hydrochloride (Jelfa, J Góra, Poland), and thioridazine hydrochloride (Jelfa, J Góra, Poland) for 5 days. The drugs were added at final concentrations indicated in appropriate figures. In the next part of the experiment, the influence of all the above-listed antipsychotic drugs at the same concentrations present in the medium for 5 days on forskolin-stimulated CAT activity was measured in differentiated Neuro-2A cells. Forskolin (Calbiochem, $25 \mu \mathrm{M}$ ) was dissolved in DMSO (the final concentration of DMSO was $0.5 \%$ ) (Sigma, St Louis, USA) and added to culture medium $24 \mathrm{~h}$ before harvesting the cells. Chlorpromazine, raclopride, and remoxipride, were dissolved in water, while clozapine, haloperidol, sulpiride, promazine, thioridazine, and risperidone were dissolved in a small amount of ethanol, followed by dilution in water (the final concentration of ethanol was below $0.5 \%$ ). The medium and the drugs in 5-day culture were changed once on day 3.

In the successive phase of the experiment, the influence of kinase and some other enzyme inhibitors and activators on the chlorpromazine- and clozapine-induced changes in the CAT activity was determined. The effects of the following compounds were tested: forskolin (PKA activator; Calbiochem); Rp-isomer of adenosine-3', $5^{\prime}$-monophosphorothioate sodium salt, a competitive inhibitor of PKA types I and II (Rp-cAMPS; BIOLOG); phorbol 12-myristate 13-acetate (TPA, RBI) an activator of PKC; U-107 (U-73122, RBI) - an inhibitor of phospholipase $\mathrm{C}$ and $\mathrm{A}_{2}$; PD 98059 (Tocris), SP 600125 (Tocris) and SB 203580 (Calbiochem) - inhibitors of extracellular signal-regulated kinase (ERK), c-Jun N-terminal kinase (JNK), and p38-MAP kinases, respectively, and wortmannin (Sigma Chemical Co.) - an inhibitor of phosphatidylinositol 3-kinase (PI3-K). Forskolin, TPA, U-107, PD 98059, SP 600125, SB 203580, and wortmannin were dissolved in DMSO (the final concentration of DMSO was $0.5 \%)$, while Rp-cAMPS solution was aqueous. The control cultures were supplemented with the same amount of an appropriate vehicle. These modulators were added alone or 30 min before chlorpromazine $(1 \mu \mathrm{M})$ or clozapine $(3 \mu \mathrm{M})$ to a culture medium for 5 days. The medium and drugs were changed once over 5-day culture.

\section{CAT Activity}

CAT activity was determined as described previously (Budziszewska et al, 2000; Pariante et al, 1997). Cell lysates were prepared by a freezing/thawing procedure. To determine CAT activity, aliquots of lysate (after heating at $60^{\circ} \mathrm{C}$ for $10 \mathrm{~min}$ ) were incubated in $0.25 \mathrm{M}$ Tris- $\mathrm{HCl}$ buffer $(\mathrm{pH}=7.8)$ with $0.25 \mu \mathrm{Ci}$ D-threo-[dichloroacetyl$1-{ }^{14} \mathrm{C}$ ]chloramphenicol and $0.2 \mathrm{mM} n$-butyryl Coenzyme A at $37^{\circ} \mathrm{C}$ for $1 \mathrm{~h}$. The butyrylated forms of chloramphenicol (in direct proportion to the CAT gene expression) were extracted twice with xylene, washed with $0.25 \mathrm{M}$ Tris- $\mathrm{HCl}$ buffer, and radioactivity was measured in a $\beta$-counter (Beckmann LS 335 liquid scintillation counter). The results are presented as d.p.m. of a butyrylated fraction of chloramphenicol per $100 \mu \mathrm{g}$ of protein per $1 \mathrm{~h}$ of incubation. The protein concentration in cell lysates was determined by the method of Lowry et al (1951).

\section{The PKA and PKC Activity Assay}

For detection of PKA and PKC activity, the cells were grown in dishes $20 \mathrm{~mm}$ in diameter in the medium containing $1 \%$ FBS for 3 days. Next, vehicle, chlorpromazine $(1 \mu \mathrm{M})$, or clozapine $(3 \mu \mathrm{M})$ was added to the culture medium for 5 days (the medium and drugs were changed once). The cells were rinsed twice in ice-cold phosphate-buffered saline and 
placed on ice. The Neuro-2A cells from two $20-\mathrm{mm}$ dishes were harvested on ice into a buffer containing $20 \mathrm{mM}$ Tris ( $\mathrm{pH}$ 7.5), $0.25 \mathrm{M}$ sucrose, $10 \mathrm{mM}$ EGTA, $2 \mathrm{mM}$ EDTA, $1 \mathrm{mM}$ phenylmethylsulfonyl fluoride, $2 \mathrm{mM}$ dithiothreitol, $0.2 \%$ IGEPAL, and $10 \mu \mathrm{g}$ per $\mathrm{ml}$ of leupeptin, pepstatin $\mathrm{A}$, and aprotinin. The cells were subjected to mild sonication, centrifuged at $20000 \mathrm{~g}$ for $10 \mathrm{~min}$ at $4^{\circ} \mathrm{C}$, and the supernatants were stored at $-80^{\circ} \mathrm{C}$. Enzyme assays were performed using the PepTag kits from Promega Corp. according to the manufacturer's instructions, as described previously (Basta-Kaim et al, 2005; Karege et al, 2004). The PepTag assay for PKA utilizes a colored, fluorescent peptide substrate (f-kemptide) as the PKA substrate. Phosphorylation of this peptide changes its net charge from +1 to -1 , which permits to separate the phosphorylated peptide from a nonphosphorylated one by electrophoresis. Neuro-2A total cell lysates $(8 \mu \mathrm{g}$ proteins) were incubated in a final volume of $25 \mu \mathrm{l}$ (reaction buffer, $2 \mu \mathrm{g}$ of f-kemptide, $5 \mu \mathrm{M}$ cAMP) at room temperature for $30 \mathrm{~min}$. Basal PKA activity was determined in the absence of cAMP. Different amounts of kemptide (from 0.25 to $2.0 \mu \mathrm{g}$ ) were used to construct a standard curve. The positive control, containing a catalytic subunit of PKA (10 ng) instead of the samples, and the negative control without PKA and the sample were included in each set of experiments. The reaction was stopped by placing the tube in boiling water for $10 \mathrm{~min}$. Then the samples were separated on a $0.8 \%$ agarose gel at $100 \mathrm{~V}$ for $20 \mathrm{~min}$. Phosphorylated peptide migrated toward the anode, while the nonphosphorylated form shifted toward the cathode. The bands were visualized under UV light and the phosphorylated bands were excised, melted, adjusted to $250 \mu \mathrm{l}$ with water, and added to gel solubilization solution. Fluorescence in relative fluorimetric units (RFU) was read at $590 \mathrm{~nm}$ (emission) with excitation at $540 \mathrm{~nm}$ in Fluoroscan Ascent (Labsystem). The results were calculated from the standard curve and expressed in nanomoles of phosphokemptides formed within a minute per $1 \mathrm{mg}$ of protein.

The PepTag assay for PKC was performed as described for PKA, except that we used: $\mathrm{C} 1$ peptide, which is highly specific for PKC (P-L-S-R-T-L-S-V-A-A-K), phosphatidylserine $(1 \mathrm{mg} / \mathrm{ml})$ as PKC activator, PKC $(10 \mathrm{ng})$ for positive control, and higher amount of cell lysates $(25 \mu \mathrm{g}$ proteins). Different amounts of $\mathrm{C} 1$ peptide (from 0.025 to $2.0 \mu \mathrm{g}$ ) were used to construct a standard curve.

\section{Western Blot}

The cells were washed twice with phosphate-buffered saline and were lysed with lysis buffer: $20 \mathrm{mM}$ Tris, $\mathrm{pH} 7.5$, $150 \mathrm{mM} \mathrm{NaCl}, 2 \mathrm{mM}$ EDTA, $2 \mathrm{mM}$ EGTA, $1 \mathrm{mM}$ sodium orthovanadate, $1 \mathrm{mM}$ phenylmethanesulfonyl fluoride, $0.2 \mathrm{nM}$ okadaic acid, $1 \mathrm{mM}$ sodium fluoride, $0.2 \%$ IGEPAL, and $10 \mu \mathrm{g} / \mathrm{ml}$ of each leupeptin, aprotinin, and pepstatin A. The lysates were collected, sonicated for $10 \mathrm{~s}$, centrifuged at $20000 \times \mathrm{g}$ for $15 \mathrm{~min}$ at $4^{\circ} \mathrm{C}$, and supernatants were collected.

Nuclear extracts were made as described by Smith et al (2000). Harvested cells were resuspended in buffer: $10 \mathrm{mM}$ HEPES, pH 7.4, $1 \mathrm{mM}$ EDTA, $2 \mathrm{mM}$ dithiothreitol, $10 \mathrm{mM}$ sodium molybdate, $10 \%$ glycerol, $1 \mathrm{mM}$ sodium orthovanadate, $1 \mathrm{mM}$ phenylmethanesulfonyl fluoride, $0.2 \mathrm{nM}$ okadaic acid, $1 \mathrm{mM}$ sodium fluoride, and $10 \mu \mathrm{g} / \mathrm{ml}$ of each leupeptin, aprotinin, and pepstatin A. The cells were homogenized using a Teflon glass Thomas homogenizer (1200 r.p.m.), centrifuged at $800 \mathrm{~g}$ for $10 \mathrm{~min}$ at $4^{\circ} \mathrm{C}$, the nuclear precipitates were washed and resuspended in buffer with $250 \mathrm{mM} \mathrm{NaCl}$. After incubation on ice for $30 \mathrm{~min}$, the samples were centrifuged at $30000 \mathrm{~g}$ for $20 \mathrm{~min}$ at $4^{\circ} \mathrm{C}$ to obtain a nuclear extract.

The cell lysates or nuclear extract (equal amount of protein) and the buffer (100 mM Tris- $\mathrm{HCl}, 4 \%$ SDS, $20 \%$ glycerol, $10 \%$ 2-mercaptoethanol, $0.005 \%$ bromophenol blue, $\mathrm{pH}=6.8$ ) were mixed and boiled for $5 \mathrm{~min}$ before loading on the gel. Proteins were separated by SDS-PAGE (4\% stacking gel, 7.5\% resolving gel for Akt and phosphoAkt; $10 \%$ for phospho-CREB and GSK-3) under constant voltage $(60 \mathrm{~V}$ in stacking gel; $120 \mathrm{~V}$ in resolving gel), and were transferred electrophoretically to the PVDF membrane (Boehringer Mannheim) at a $60 \mathrm{~V}$ constant current for $2 \mathrm{~h}$. The membranes were washed twice with the Tris-buffered saline (TBS), $\mathrm{pH}=7.5$, blocked in a $1 \%$ blocking solution (Boehringer Mannheim) for $1 \mathrm{~h}$, and incubated overnight at $4{ }^{\circ} \mathrm{C}$ with the primary antibody anti-phospho-Akt Ser-473 (Santa Cruz Biotechnology, Inc.), anti-Akt (BD Pharmingen), anti-phospho-CREB Ser-133 (Sigma Chemical Co.), and anti-GSK-3 $\beta$ (Sigma Chemical Co.). The blots were washed: twice with TBS containing a $0.1 \%$ Tween-20 (TBST); twice with a $0.5 \%$ blocking solution in TBS, and were then incubated with a horseradish peroxidase-linked secondary antibody (anti-rabbit/anti-mouse IgG; $40 \mathrm{mU} / \mathrm{ml}$; Boehringer Mannheim) for $1 \mathrm{~h}$ at a room temperature. Afterwards, the membranes were washed four times with large volumes of TBST, and immunoblots were visualized with a chemiluminescence detection kit (Boehringer Mannheim). The semiquantitative analysis of band intensity was performed using FujiLas 1000 and FujiGauge software.

\section{Effect of Antipsychotic Drugs on Cell Viability}

Neuro-2A cells were treated with the vehicle or antipsychotic drugs (at concentrations used in the CRH-CAT study) for 5 days. The effect of drugs on cell viability was determined by counting viable and nonviable (blue) cells in a hemocytometer. The cell suspensions were mixed (at $1: 1$ ratio) with a $0.4 \%$ trypan blue, and the number of nonviable cells per total of 100 cells was counted.

\section{Statistical Analysis}

The data are presented as the means \pm SEM of two to three independent experiments, and the significance of differences between the means has been evaluated by Duncan's test, following one-way or two-way analysis of variance, respectively.

\section{RESULTS}

\section{Effect of Antipsychotic Drugs on Basal CRH Gene Promoter Activity in Neuro-2A Cells}

Neuro-2A cells grown in the medium containing $1 \%$ serum proliferated slightly and about $80 \%$ of the cells formed long neurites. A basal CRH promoter activity in differentiated Neuro-2A cells stably transfected with hCRH ( -663 to 
+ 124 bp)-CAT construct was high (32 000 \pm 573 d.p.m./100 $\mu \mathrm{g}$ protein/h). Treatment of the cells with chlorpromazine, clozapine, and haloperidol $(0.1-5 \mu \mathrm{M})$ for 1 or 3 days had no statistically significant effect on basal CAT activity (data not shown). The significant effects appeared after 5 days of the presence of some antipsychotics drugs in culture medium. Chlorpromazine $(0.1-5.0 \mu \mathrm{M})$ in a concentration-dependent manner inhibited CAT activity. Treatment of cells with haloperidol $(0.5-5.0 \mu \mathrm{M})$, clozapine $(1.0-5.0 \mu \mathrm{M})$, thioridazine $(1.0-5.0 \mu \mathrm{M})$, promazine $(5.0$ and $10 \mu \mathrm{M})$, as well as with risperidone $(5.0$ and $10.0 \mu \mathrm{M})$ decreased $\mathrm{CRH}$ gene promoter activity. Raclopride inhibited the CAT activity only at the highest used concentrations (30 and $100 \mu \mathrm{M})$, while sulpiride and remoxipride had no effect (Figure 1a-c;

a
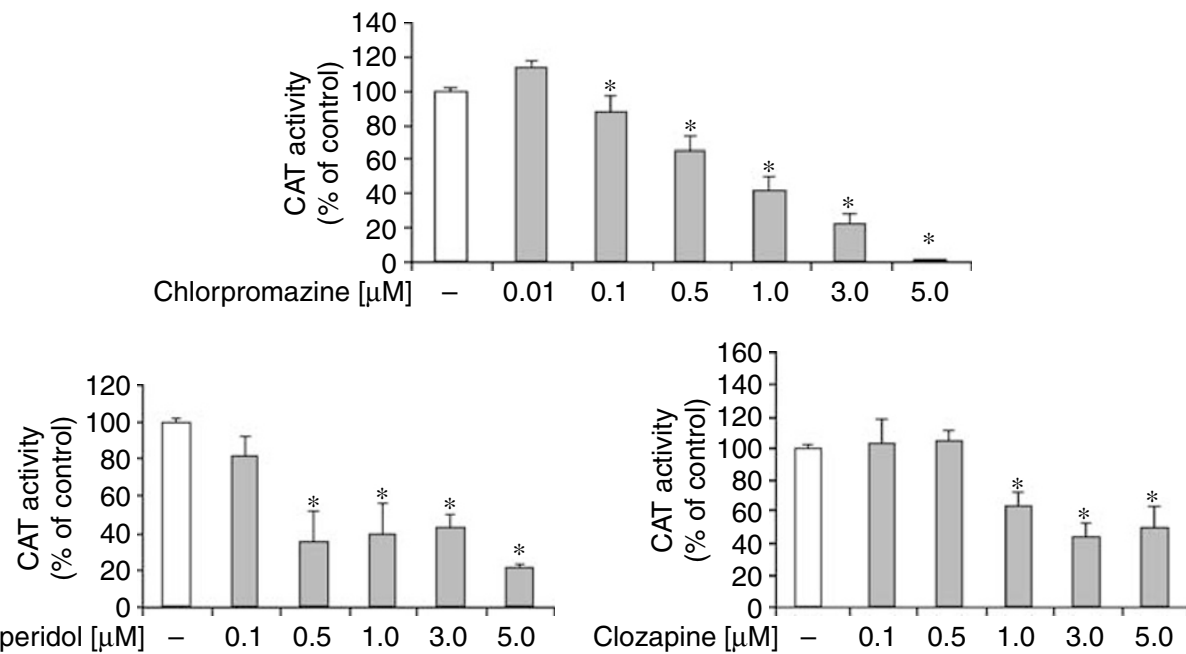

b
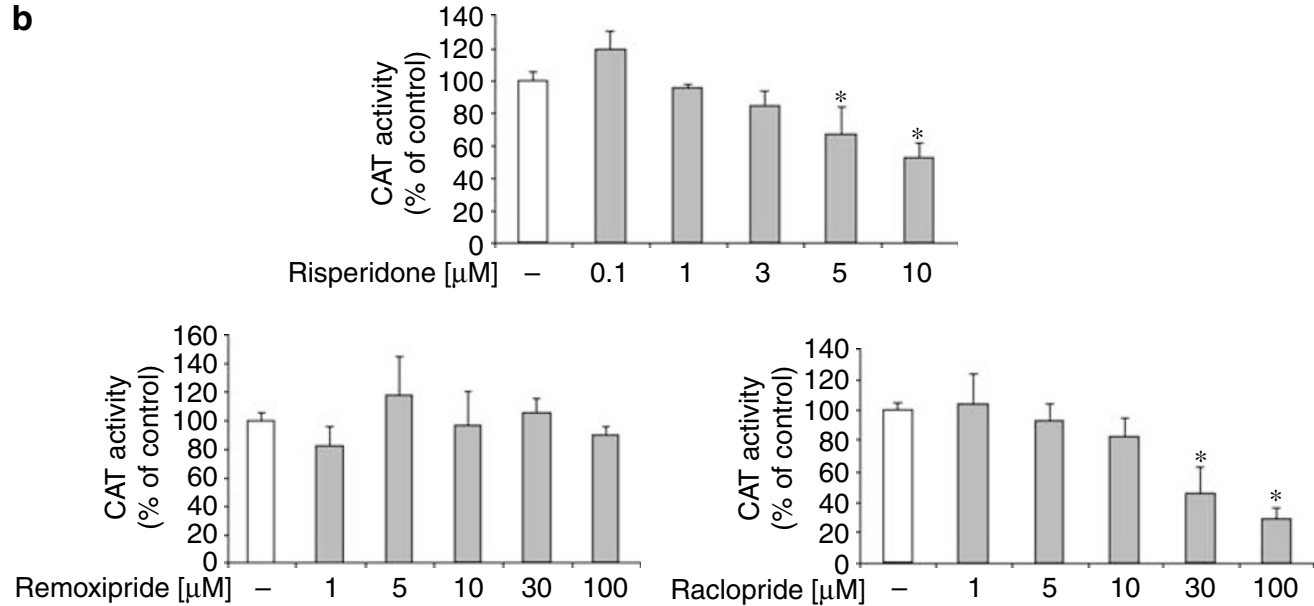

C
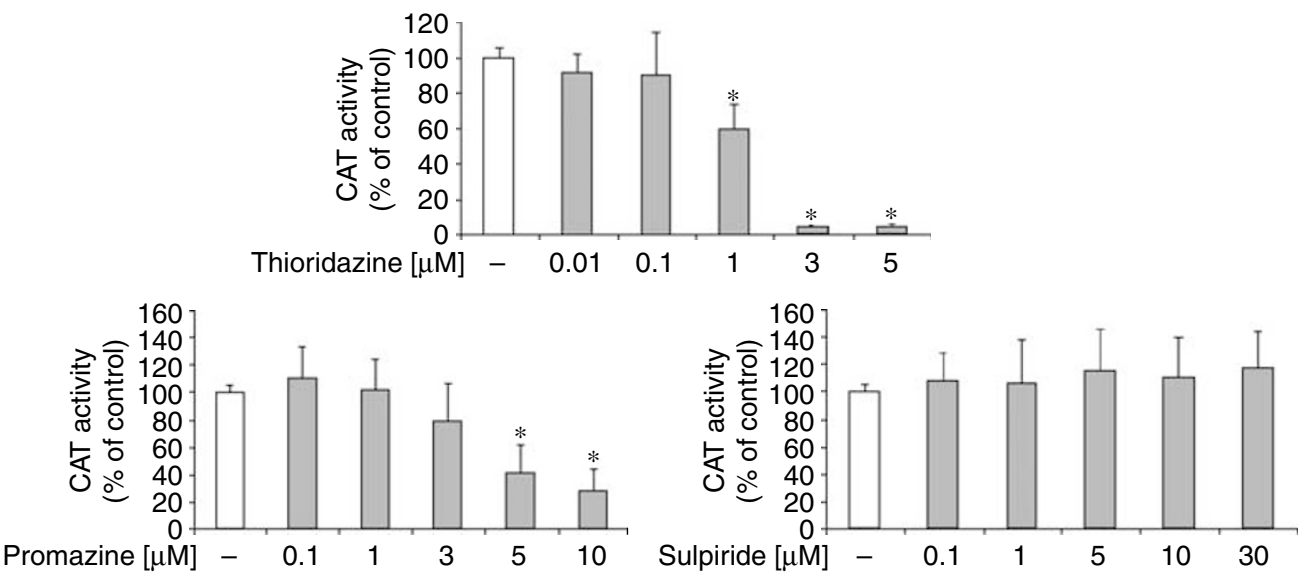

Figure I $(a-c)$ The effect of antipsychotic drugs applied at the indicated concentrations for 5 days on the CAT gene transcription in Neuro-2A cells stably transfected with pCRH-CAT plasmid. The data are calculated as d.p.m. of the butyrylated fraction of chloramphenicol per $100 \mu \mathrm{g}$ of protein per I h of incubation from three separate experiments and presented as a percentage \pm SEM of control (culture with appropriate vehicle only). The significance of differences between the means was evaluated by the Dunnett's test following a one-way analysis of variance (*p $<0.0$ I vs control group). 
Table I Effect of Antipsychotic Drugs on the $\mathrm{CRH}$ Gene Promoter Activity

\begin{tabular}{lcc}
\hline Drug & $\begin{array}{c}\text { CRH basal } \\
\text { activity }\end{array}$ & $\begin{array}{c}\text { CRH forskolin- } \\
\text { induced activity }\end{array}$ \\
\hline Chlorpromazine & $0.1^{\mathrm{a}}$ & 1.0 \\
Haloperidol & 0.5 & 1.0 \\
Clozapine & 1.0 & 1.0 \\
Risperidone & 5.0 & - \\
Remoxipride & - & - \\
Raclopride & 30.0 & 30.0 \\
Thioridazine & 1.0 & 3.0 \\
Promazine & 5.0 & - \\
Sulpiride & - & - \\
\hline
\end{tabular}

The lowest drug concentration (in $\mu \mathrm{M}$ ) that in statistically significant manner inhibited CRH promoter activity; —, lack of effect.

Table 1). A basal CAT activity in Neuro-2A cells transfected with plasmid containing hCMV instead of hCRH promoter was high $(250000 \pm 900$ d.p.m./100 $\mu$ g protein/h), but none of the antipsychotic drugs (used at the same concentration as in testing the hCRH promoter activity) had any effect (data not shown).

\section{Effect of Antipsychotic Drugs on Forskolin-Induced CRH Gene Promoter Activity in Neuro-2A Cells}

Forskolin $(25 \mu \mathrm{M})$, present in culture medium for $24 \mathrm{~h}$, increased about three-fold the CAT activity in differentiated Neuro-2A cells. The most potent inhibition of forskolininduced CAT activity was found after treatment of the cells with chlorpromazine $(1.0-5.0 \mu \mathrm{M})$ and haloperidol $(1.0-5.0 \mu \mathrm{M})$, but the dose-dependent inhibitory effect on the $\mathrm{CRH}$ gene promoter activity was also observed after clozapine $(1.0-5.0 \mu \mathrm{M})$, thioridazine $(3.0$ and $5.0 \mu \mathrm{M})$, and raclopride $(30$ and $100 \mu \mathrm{M})$. Other drugs under study (promazine, sulpiride, risperidone, and remoxipride) had no effect on the forskolin-induced CRH-CAT activity (Figure 2a-c, Table 1).

The Effect of Some Protein Kinase Modulators on Basal and Chlorpromazine- and Clozapine-Induced Inhibition of CRH Gene Promoter Activity

Treatment of stably transfected differentiated Neuro-2A cells with forskolin $(25 \mu \mathrm{M})$ for 5 days potently increased the CAT activity. Inhibitor of PI3-K - wortmannin $(0.1 \mu \mathrm{M})$ also enhanced CRH-CAT activity, but to a lower degree than forskolin. On the other hand, an inhibitor of PKA-RpcAMPS $(50 \mu \mathrm{M})$ and inhibitors of ERK-, JNK-, and p38MAP kinases (PD 98059, SP 600125, SB 203589) at higher doses attenuated the basal activity of $\mathrm{CRH}$ gene promoter. The activator of PKC (TPA) and phospholipase $\mathrm{C}$ inhibitor (U-107) had no effect on reporter gene activity (Figure 3 ).

In the next part of the study, the influence of some kinase modulators on chlorpromazine- and clozapine-evoked inhibition of the CAT activity was determined. We selected $1 \mu \mathrm{M}$ chlorpromazine and $3 \mu \mathrm{M}$ clozapine, which inhibited
CAT activity by about $60 \%$ (Figures 4 and 5 ). Wortmannin, an inhibitor of PI3-K used at the concentrations which did not change the basal CRH-CAT activity $(0.01$ and $0.02 \mu \mathrm{M})$, in a statistically significant manner attenuated chlorpromazine action (Figure 4). Clozapine-evoked CRH-CAT activity was in a statistically significant manner attenuated by wortmannin at 0.01 and $0.02 \mu \mathrm{M}$ concentration, as well as by the PKC activator (TPA; $0.1 \mu \mathrm{M}$ ) (Figure 5). Other modulators under study, used at concentrations which did not affect basal CRH-CAT activity, that is, an inhibitor of phospholipase C (U107; $1 \mu \mathrm{M})$, inhibitor of PKA (RpcAMPS; $25 \mu \mathrm{M}$ ), inhibitors of ERK-MAPK (PD 98059; $15 \mu \mathrm{M}$ ), JNK-MAPK (SP 600125; $0.2 \mu \mathrm{M}$ ), and p38-MAPK (SB 203580; $1 \mu \mathrm{M}$ ) did not change chlorpromazine as well as clozapine action (data not shown).

\section{Effect of Chlorpromazine and Clozapine on PKA and PKC Activity}

PKA activity was determined by PegTag nonradioactive assay, calculated as the nmol of phospho-kemptide per minute per mg of protein and presented as a percentage \pm SEM of control culture (with appropriate vehicle only). The basal and cAMP-stimulated PKA activity was high in differentiated Neuro-2A cell. As shown in Figure 6, chlorpromazine present in culture medium for 5 days had no effect on the basal and cAMP-induced PKA activity. Clozapine did not change the basal, but attenuated cAMPstimulated PKA activity. In contrast to PKA, PKC activity in Neuro-2A cells was low. Chlorpromazine $(1 \mu \mathrm{M})$ present in culture medium for 5 days had no effect on the phosphatidylserine-stimulated PKC activity, while clozapine $(3 \mu \mathrm{M})$ in a statistically significant manner decreased this parameter (Figure 6).

\section{Effect of Chlorpromazine and Clozapine on Phospho-Akt, Total Akt, Phospho-CREB and GSK-3 $\beta$ Levels}

Treatment of differentiated Neuro-2A cells for 5 days with chlorpromazine $(1 \mu \mathrm{M})$ or clozapine $(3 \mu \mathrm{M})$ resulted in a significant increase in Ser-473-phosphorylated Akt level, without changing total levels of Akt (Figure 7). As phosphorylated, activated PKB (Akt) is able to directly phosphorylate and inhibit the activity of GSK-3, the effect of chlorpromazine and clozapine on the level of active, nonphospohorylated form of GSK-3 $\beta$ was also determined. It has been found that both used drugs decreased the GSK$3 \beta$ level in a statistically significant manner (Figure 7 ). Since phospho-CREB is the main transcription factor involved in $\mathrm{CRH}$ gene regulation, the effect of chlorpromazine and clozapine on its level was evaluated. It has been found that no drugs change the phospho-Ser-133-CREB level in a nuclear fraction of Neuro-2A cells.

\section{Effect of Antipsychotic Drugs on Cell Viability}

None of the antipsychotic drugs used in the present study evoked toxic effect, estimated by counting nonviable cells in differentiated Neuro-2A cells (data not shown). 


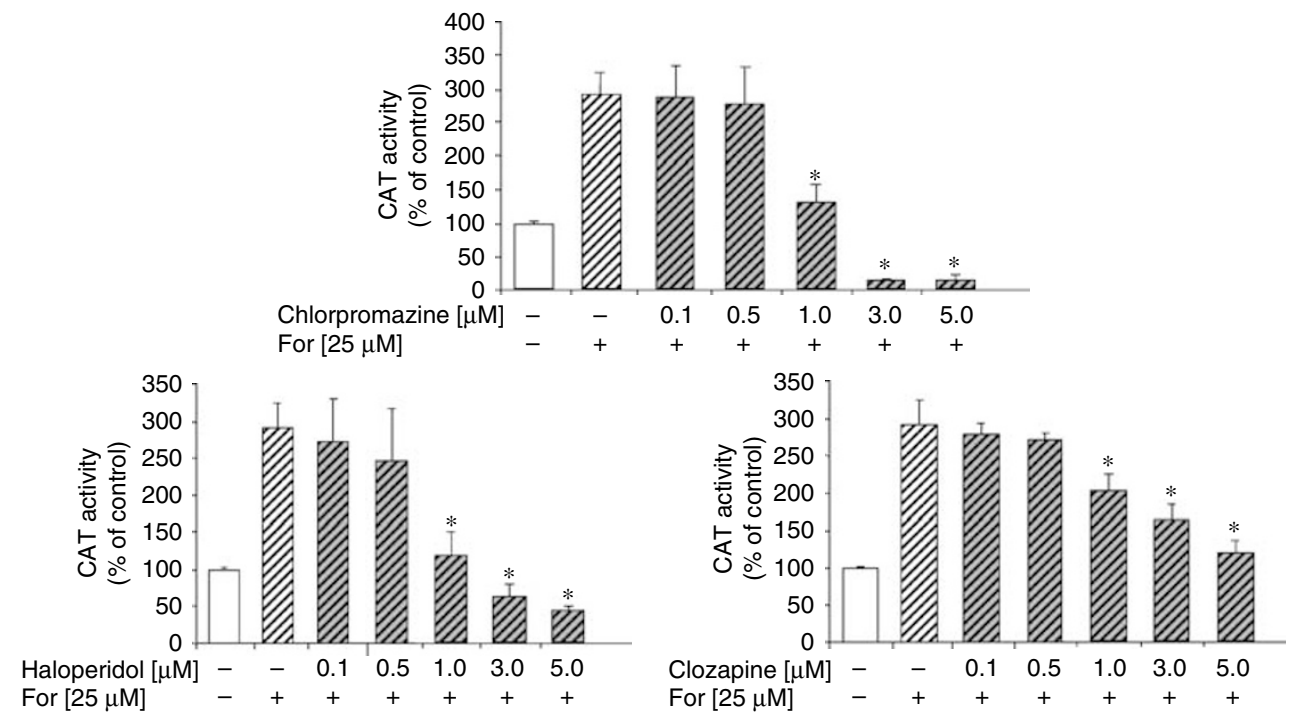

b
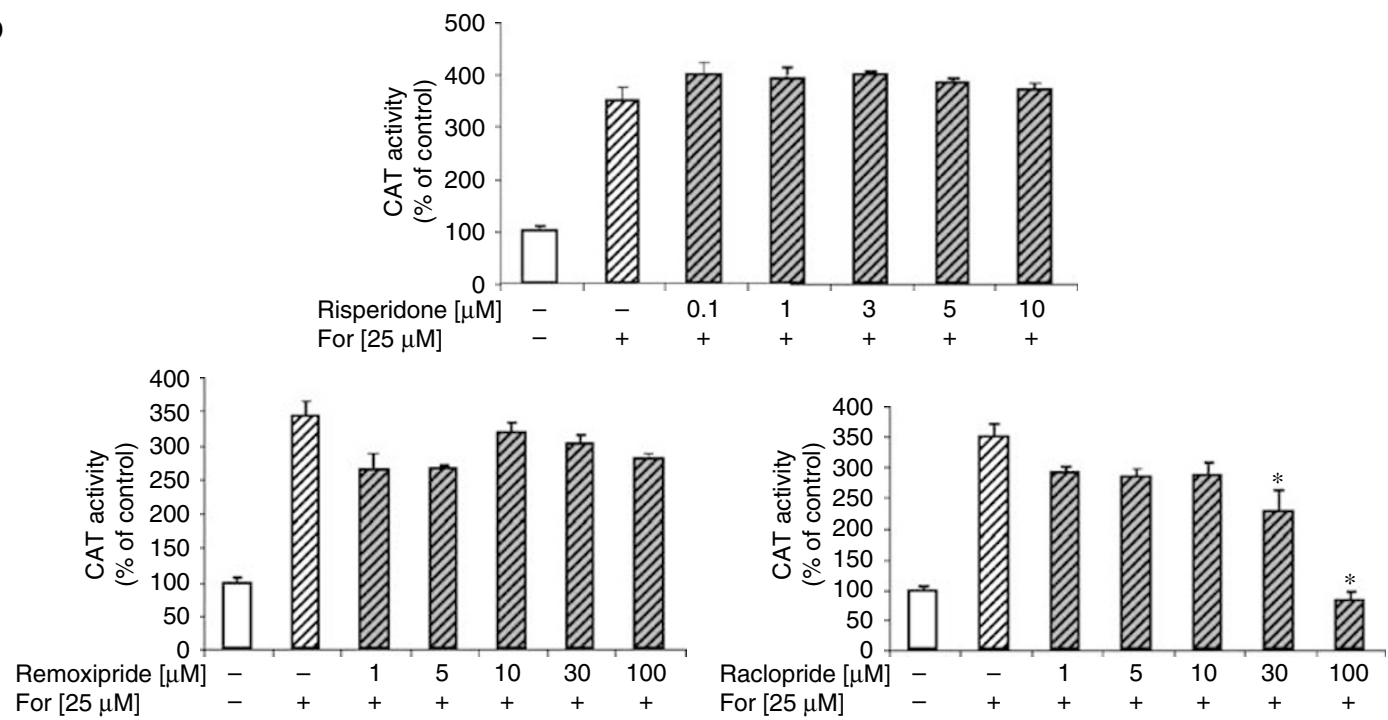

C
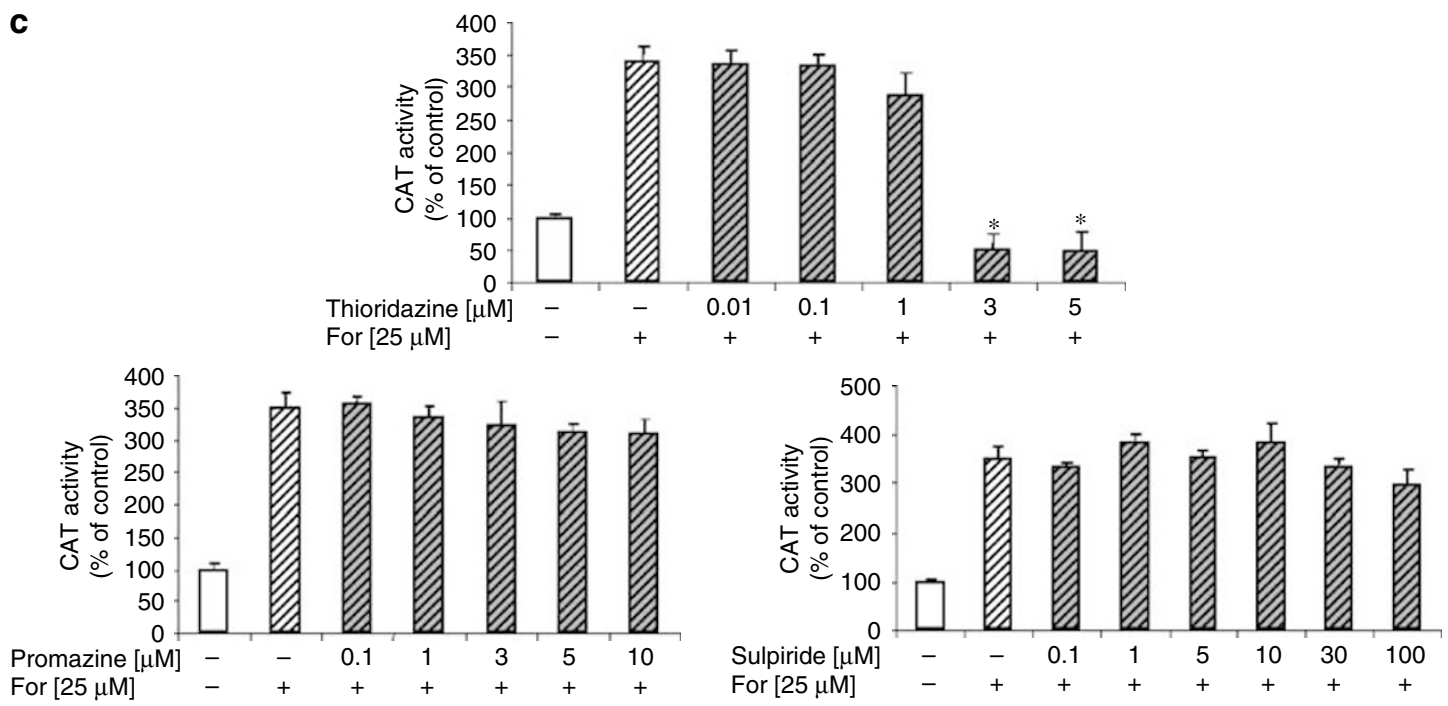

Figure $2 \mathrm{a}-\mathrm{c}$ ) The effect of antipsychotic drugs applied at the indicated concentrations for 5 days on the forskolin (For; $25 \mu \mathrm{M}, 24 \mathrm{~h}$ )-induced CAT gene transcription in Neuro-2A cells stably transfected with PCRH-CAT plasmid. The data were calculated as d.p.m. of the butyrylated fraction of chloramphenicol per $100 \mu \mathrm{g}$ of protein per I h of incubation from three separate experiments, and are presented as a percentage \pm SEM of control (culture with appropriate vehicle only). The significance of differences between the means was evaluated by the Dunnett's test following a two-way analysis of variance $(* p<0.0$ I vs control group). 


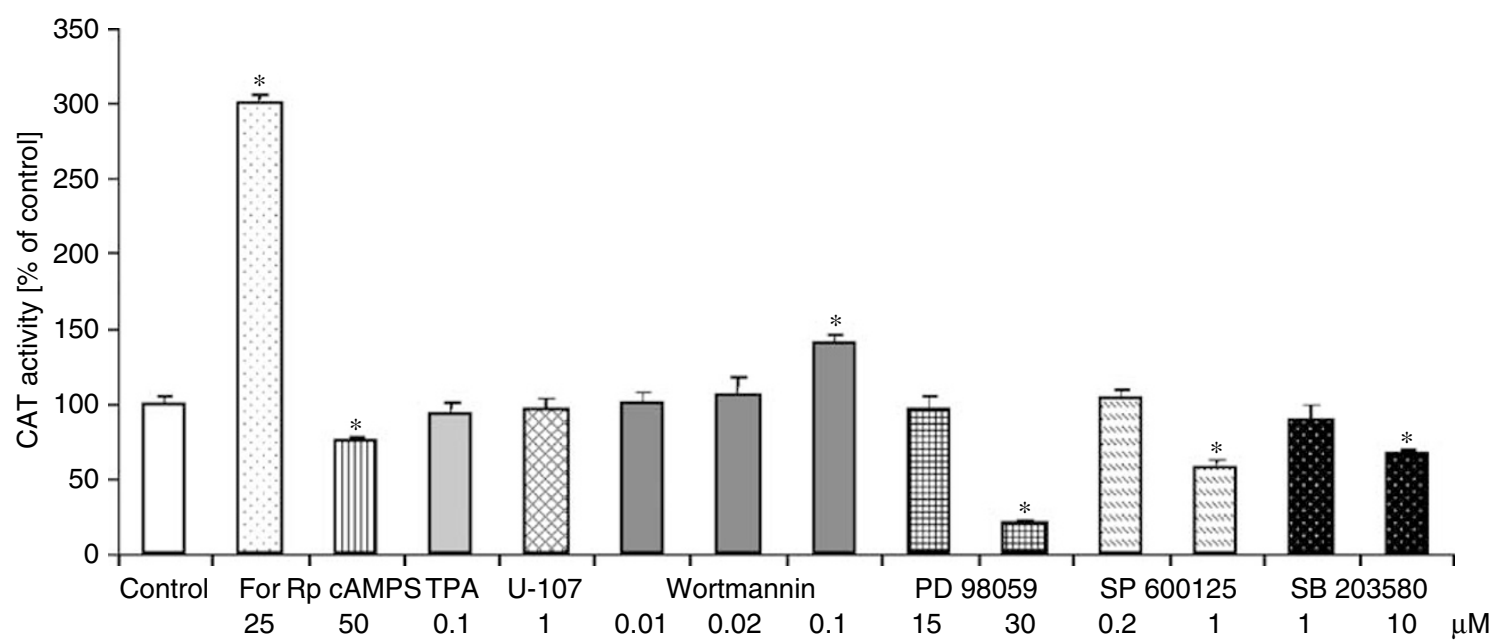

Figure 3 The effect of PKA activator-forskolin (For); PKA inhibitor-Rp-cAMPS; PKC activator (TPA); phospholipase C inhibitor (U-I07); PI3-K inhibitor - wortmannin; ERK-MAPK inhibitor-PD 98059; JNK-MAPK inhibitor - SP 600125 and p38-MAPK inhibitor-SB 203580, applied at the indicated concentrations for 5 days, on the CAT gene transcription in differentiated Neuro-2A cells stably transfected with pCRH-CAT plasmid. The data were calculated as d.p.m. of the butyrylated fraction of chloramphenicol per $100 \mu \mathrm{g}$ of protein per I h of incubation from two separate experiments and are presented as a percentage \pm SEM of control (culture with appropriate vehicle only). The significance of differences between the means was evaluated by the Dunnett's test following a one-way analysis of variance (* $p<0.01$ vs control group).

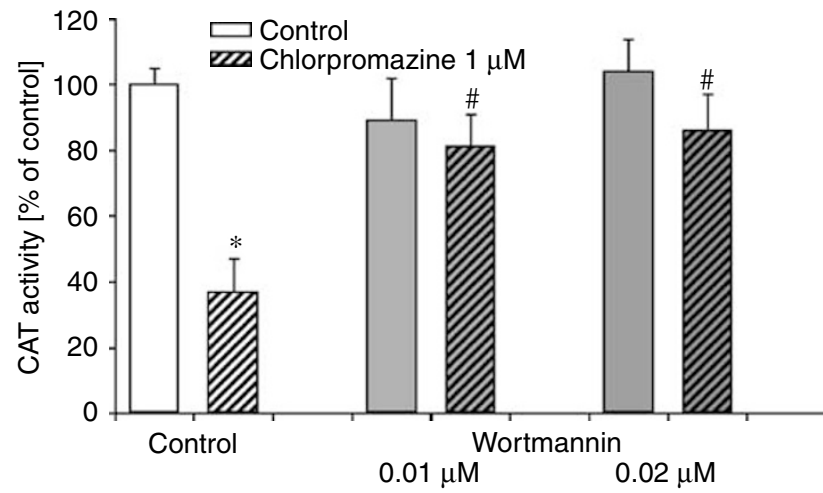

Figure 4 The effect of $\mathrm{PI} 3-\mathrm{K}$ inhibitor (wortmannin) on chlorpromazineinduced inhibition of CAT gene transcription in Neuro-2A cells stably transfected with pCRH-CAT plasmid. Drugs were applied at the indicated concentrations for 5 days. The data were calculated as d.p.m. of the butyrylated fraction of chloramphenicol per $100 \mu \mathrm{g}$ of protein per I h of incubation from three separate experiments and are presented as a percentage $\pm S E M$ of control (culture with appropriate vehicle only). The significance of differences between the means was evaluated by the Dunnett's test following a two-way analysis of variance $(* p<0.0$ I vs control group, ${ }^{\#} p<0.01$ vs chlorpromazine group).

\section{DISCUSSION}

The main finding of the present study was the demonstration that a majority of antipsychotic drugs under study markedly inhibited the basal activity of CRH gene promoter. The most potent effect in this respect was exerted by chlorpromazine, haloperidol, clozapine, and thioridazine, whereas promazine, risperidone, and raclopride were less active. Out of nine studied antipsychotic drugs, only sulpiride and remoxipride had no effect. Assuming that antipsychotic drugs have similar effects on $\mathrm{CRH}$ gene transcription in the hypothalamus, this may be an important part of molecular mechanism by which these drugs regulate HPA axis activity. Moreover, we found that inhibitory effects of antipsychotics are time-dependent,

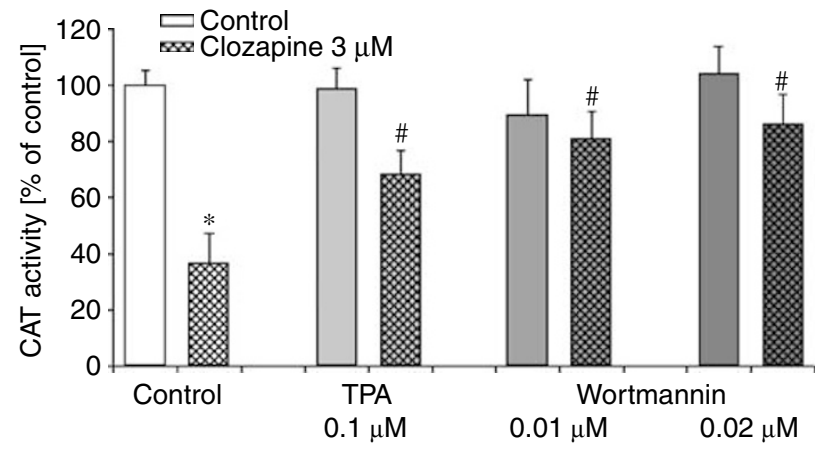

Figure 5 The effect of PKC activator (TPA) and PI3-K inhibitor (wortmannin) on clozapine-induced inhibition of CAT gene transcription in Neuro-2A cells stably transfected with PCRH-CAT plasmid. Drugs were applied at the indicated concentrations for 5 days. The data were calculated as d.p.m. of the butyrylated fraction of chloramphenicol per $100 \mu \mathrm{g}$ of protein per I h of incubation from three separate experiments and are presented as a percentage \pm SEM of control (culture with appropriate vehicle only). The significance of differences between the means was evaluated by the Dunnett's test following a two-way analysis of variance ( $p<0.0$ I vs control group, $\# p<0.0$ I vs clozapine group).

because 5 , but not 1 and 3, days of treatment of the cells with chlorpromazine, clozapine, and haloperidol had a statistically significant inhibitory effect on basal CAT activity.

Although it is not possible to directly compare the timedependent effect seen in in vivo experiments with that obtained in vitro, it should be stressed that similar changes as those observed after long-term administration of psychotropic drugs in experimental animals are also present in vitro after their 3-5-days presence (depending on concentration) in culture medium (Donati et al, 2001; Lai et al, 2003). Since no data are available on the effect of chronic treatment with particular antipsychotic drugs on $\mathrm{CRH}$ concentration in vivo, the present results can be related only to antipsychotic-induced changes in corticosterone blood level. It should be mentioned that acute 
treatment with antipsychotic drugs, especially atypical ones, increases the plasma concentration of glucocorticoids in humans and experimental animals (Aimoto et al, 1981; Gudelsky et al, 1989a,b; Gudelsky and Nash, 1992); however, repeated administration of these drugs significantly decreases the concentration of cortisol in humans and corticosterone in rats (Chan and Holmes, 1978; Hung and Chan, 1981; Kahn et al, 1993; Ryan et al, 2004; Sweep et al, 1990). Nevertheless, chlorpromazine and haloperidol, which in the present study strongly inhibited CRH activity, also after chronic treatment decreased corticosterone level in rats (Chan and Holmes, 1978; Hung and Chan, 1981; Sweep et al, 1990). There are only a few data concerning the effects of long-term treatment with antipsychotics on HPA

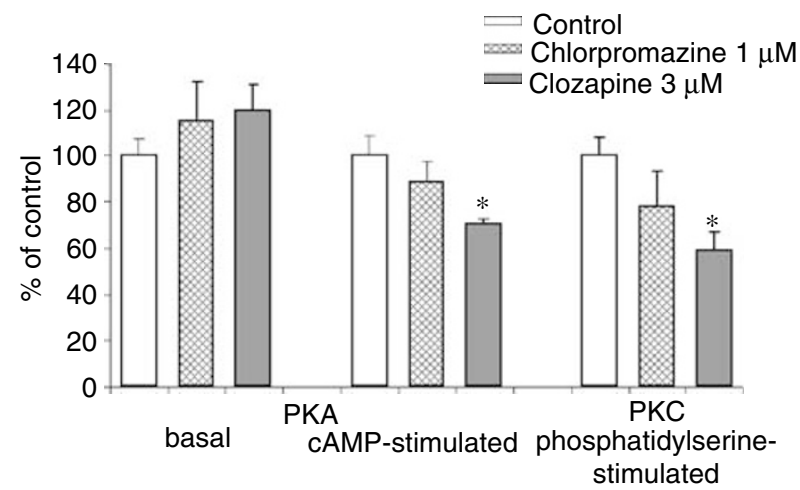

Figure 6 The effect of chlorpromazine and clozapine applied at the indicated concentrations for 5 days on PKA (basal and cAMP-stimulated) and phosphatidylserine-stimulated PKC activity in differentiated Neuro-2A cells. Cell lysates were prepared as described in Materials and methods section, and tested in the PepTag nonradioactive PKA and PKC assay, respectively. The data were calculated as the $\mathrm{nmol} / \mathrm{min} / \mathrm{mg}$ of protein (phospho-kemptide for PKA; phospho-CI for PKC) from three separate experiments and are presented as a percentage \pm SEM of control culture (with appropriate vehicle only). The significance of differences between the means was evaluated by the Dunnett's test following a one-way analysis of variance ( $p<0.0$ I vs control group). axis activity, so a possible correlation between their effect on CRH gene activity and the action on glucocorticoid levels in vivo cannot be easily demonstrated. Assuming that antipsychotic drugs inhibit both hypothalamic and extrahypothalamic (eg amygdala, locus coeruleus) CRH synthesis, they may antagonize not only the glucocorticoids action but also may reduce the $\mathrm{CRH}$-related neuronal excitability, dopamine release, anxiety, and mood disturbances. Although the pathomechanism of schizophrenia has not been elucidated yet, an interaction of CRH and dopamine in the ventral mesencephalon has been suggested to play a role in stress-related exacerbation of this disorder (Austin et al, 1997).

A functional CRE is present in the CRH gene promoter and many studies have demonstrated that activation of the PKA in cells, which contain CREB, leads to stimulation of CRH promoter (Budziszewska et al, 2002, 2004; GuardiolaDiaz et al, 1994; Nikodemova et al, 2003; Seasholtz et al, 1988; Spengler et al, 1992). However, action of forskolin depends also upon the types and levels of adenylyl cyclase and phosphodiesterase isoforms expressed in cells, so marked differences are observed in CRH responses to forskolin (Nikodemova et al, 2003). In line with our previous data, a cAMP/PKA pathway activator, forskolin, about three-fold enhanced CRH-CAT activity in differentiated Neuro-2A cells (Budziszewska et al, 2004), while in another cell line a much larger increase was observed (Seasholtz et al, 1988). Furthermore, it has been found that stress-induced $\mathrm{CRH}$ synthesis in the hypothalamic neurons is most probably evoked by cAMP-PKA pathway activation, and in consequence the increased phosphorylation of CREB (Legradi et al, 1997). Since forskolin-stimulated CRH activity was inhibited by clozapine, chlorpromazine, haloperidol, and thioridazine, it can be expected that these drugs should also inhibit stress-stimulated CRH synthesis. In fact, haloperidol - which decreased forskolin-induced CRH activity - has been found to inhibit stress-induced rise in plasma corticosterone in rats (Keim and Sigg, 1977).
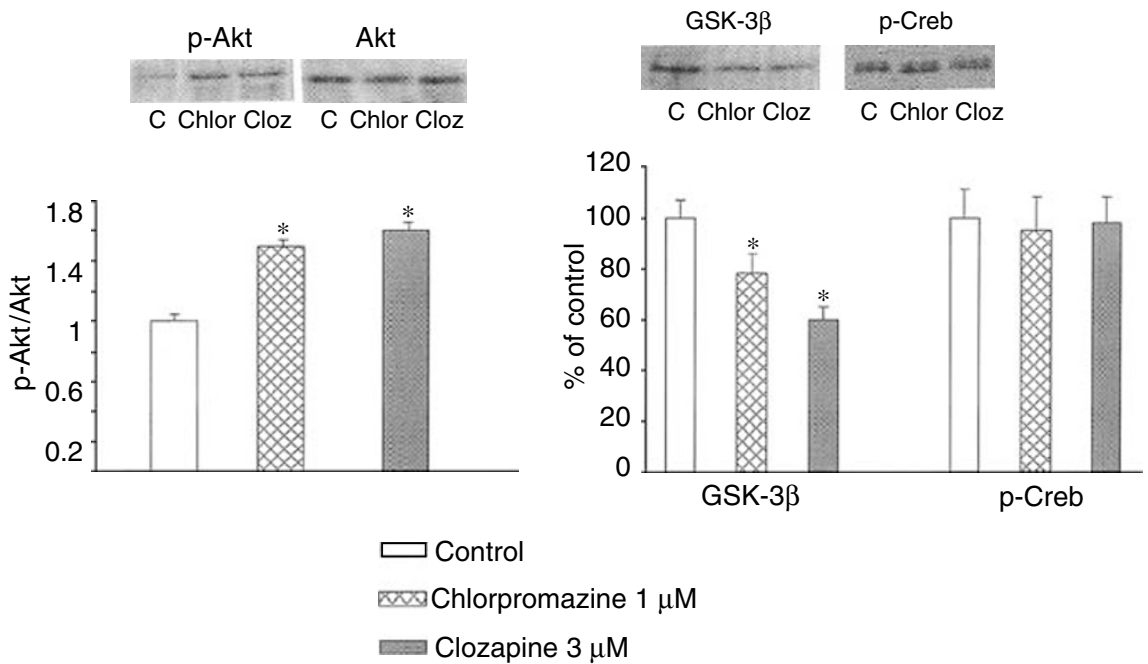

Figure 7 The effect of chlorpromazine and clozapine applied at the indicated concentrations for 5 days on phospho-Ser-473-Akt (p-Akt), total Akt and GSK-3 $\beta$ in cell lysates and phospho-Ser-133-CREB level in the nuclear fraction of differentiated Neuro-2A cells. Results (mean \pm SEM) from two separate experiments are expressed as a percentage of the vehicle-treated cells. The significance of differences between the means was evaluated by the Dunnett's test following a one-way analysis of variance ( ${ }^{*} p<0.0$ I vs control group). 
However, the effect of chronic treatment with other antipsychotics during stress on HPA axis activity has not been studied. Among the drugs under study, sulpiride, remoxipride, and raclopride (up to $10 \mu \mathrm{M}$ ) had no effect on the basal as well as on the forskolin-stimulated $\mathrm{CRH}$ activity. Ineffectiveness of these drugs can be due to their too low intracellular concentrations or due to the lack of their action on elements involved in $\mathrm{CRH}$ gene regulation in Neuro-2A cells. In contrast to the well-known action of antipsychotics on neurotransmitter receptors, their effect on intracellular pathway and gene transcription regulation are poorly recognized. Neuro-2A cells contain serotonin and serotonin transporters, but little amount of dopamine (Chatterjee et al, 1992). They contain muscarinic, opioid, angiotensin, bradykinin, thyroid, and neurotrophin receptors; however, no data concerning the presence of serotonin receptors in these cells are available. Neuro-2A cells endogenously express $4.1 \mathrm{~N}$ protein (a D2-like dopamine receptor-interacting protein), but virtually no specific binding to dopamine receptors in undifferentiated cells was found (Binda et al, 2002; Monsma et al, 1989). As we did not find a correlation between action of antipsychotics on $\mathrm{CRH}$ promoter and their effects on dopamine (for example, sulpiride $v s$ haloperidol) or serotonin (klozapine $v s$ risperidone) receptors, we suggested that in this cell line antipsychotics inhibited $\mathrm{CRH}$ promoter via another target than dopamine or serotonin receptors.

Chlorpromazine, clozapine, and haloperidol, but not sulpiride, remoxipride, and raclopride inhibited transcriptional function of not only $\mathrm{CRH}$ gene but also another gene connected with regulation of HPA axis, for example, GRmediated gene transcription (Basta-Kaim et al, 2002). It seems that the influence of antipsychotics on the $\mathrm{CRH}$ activity, similarly as on GR function, depends on their action on protein kinases, involved in $\mathrm{CRH}$ regulation. As we have found previously and confirmed in the present study, the activity of $\mathrm{CRH}$ gene promoter in Neuro-2A cells is, besides PKA, regulated also by CaMK, MAPK, and PKB (Budziszewska et al, 2004). Inhibition of CaMK and MAPK decreased, while inhibition of $\mathrm{PKB}$ enhanced the basal activity of the investigated gene in Neuro-2A cells. Similarly, Yamamori et al (2004) found that activation of CaMK exerted a potent stimulatory effect on $\mathrm{CRH}$ gene promoter activity in human neuroblastoma cell line, but the effect of MAPK and PKB activation of $\mathrm{CRH}$ gene activity has not been studied yet.

In the present study, we estimated an involvement of protein kinases in inhibition of $\mathrm{CRH}$ activity by chlorpromazine and clozapine - two drugs, which differ between themselves in respect of their effect on the monoamine system, but which exerted strong action on CRH activity. We have found that the action of chlorpromazine and clozapine on $\mathrm{CRH}$ activity depends mainly on activation of PI3-K/Akt (PKB) pathway. Wortmannin, a selective inhibitor of PI3-K, blocked chlorpromazine and clozapine action on the activity of CRH gene promoter. Moreover, in the Western blot study, both drugs increased the level of active phospho-Akt, without changing total Akt level, and decreased the level of active, nonphosphorylated GSK-3 $\beta$. Recently, it has been postulated that alterations in Akt/ GSK-3 system play an essential role in pathogenesis of schizophrenia and in the mechanism of antipsychotic drug action. Akt is a serine/threonine kinase that regulates cell growth, glucose uptake, metabolism, and increases cell survival. A reduction in Akt levels in the frontal cortex and hippocampus of schizophrenic patients (Emamian et al, 2004) may be connected with neurodegenerative changes observed in this illness. Activated Akt phosphorylates many intracellular substrates, for example, it phosphorylates the GSK-3 $\beta$ at Ser9 and inactivates it. Emamian et al (2004) found a lower level of the phosphorylated form of GSK-3 $\beta$ in the lymphocytes and frontal cortex of schizophrenic patients compared to control subjects, however, other authors showed the attenuated activity of active, nonphosphorylated form of GSK-3 in the frontal cortex of schizophrenic patients (Kozlovsky et al, 2002). Data concerning the antipsychotic drug action on these kinases are scarce. Interestingly, only mood stabilizers (lithium and valproate), which are also used in therapy of schizophrenia, are known to phosphorylate both Akt and GSK-3 $\beta$ (Chalecka-Franaszek and Chuang, 1999; De Sarno et al, 2002). In line with our finding, which showed that the 5-day presence of chlorpromazine and clozapine in culture medium increased the level of phospho-Akt in Neuro-2A cells, it has been reported that chronic treatment with haloperidol enhanced phosphorylation of Akt in the frontal cortex of mice (Emamian et al, 2004). On the other hand, after short (30 $\mathrm{min})$ incubation, the increase in p-Akt level in PC12 cells was evoked only by olanzapine, but not clozapine, chlorpromazine, or fluphenazine (Lu et al, 2004).

Our data showed that chlorpromazine and clozapine increased Akt phosphorylation and decreased the level of the active nonphosphorylated form of GSK-3 $\beta$ in Neuro-2A cells. Antipsychotics may enhance the PI3-K/Akt pathway directly or by intensifying a neurotrophic factor action (Durany and Thome, 2004). The fact that a prolonged treatment with antipsychotic drugs was necessary to inhibit $\mathrm{CRH}$ promoter activity suggested that synthesis of some neurotrophic factors or their receptors might be required. Phospho-Akt phosphorylates GSK-3 $\beta$ at Ser-9 and inhibits its activity. As in some cell systems phosphorylation of CREB not only at Ser-133 by also at Ser-129 by GSK-3 is required for higher CREB activation, inhibition of GSK-3 $\beta$ activity by chlorpromazine and clozapine could inhibit CRH gene promoter activity (Fiol et al, 1994; Tyson et al, 2002). Moreover, since chlorpromazine and clozapine did not change the level of CREB phosphorylated at Ser-133, their action on phosphorylation of the other serine in CREB or other elements than CRE in $\mathrm{CRH}$ promoter is more probable.

In the light of neurodevelopmental hypothesis of schizophrenia (Kozlovsky et al, 2002), trophic effects of some antipsychotics should be important for their clinical effect. Positive effects of atypical antipsychotics on neuronal growth and energy metabolism are now extensively studied, so clozapine effect on $\mathrm{CRH}$ promoter (possibly via increased Akt phosphorylation) is in line with those reports. On the other hand, chlorpromazine (a typical antypsychotic, which in our model also decreased CRH promoter activity) did not share the neuroprotective effect of atypical antipsychotics, although one study showed that it protected neuroblastoma cells against hypoxic damage (Peruche and Krieglstein, 1991). Chlorpromazine is a potent inhibitor of PKC, affects steroid hormone receptor binding, and, like 
clozapine, inhibits glucose transport in PC-12 cells, so its effect on Akt phosphorylation would be connected with these actions. For example, the inhibition of PKC increased Akt phosphorylation and enhanced survival of cerebellar granule cell neurons (Zhu et al, 2004).

Although our data point to a critical role of PI3-K in chlorpromazine and clozapine-induced inhibition of $\mathrm{CRH}$ gene transcription, participation of other protein kinases, for example, PKA, PKC, CaMK, and MAPK should also be taken into account. Measurements of the activity of PKA showed that this protein kinase can be involved only in clozapine- but not chlorpromazine-evoked inhibition of the forskolin-stimulated $\mathrm{CRH}$ gene activity. Besides Akt and PKA, also CaMK and MAP kinases participate in the regulation of basal activity of CRH promoter in Neuro-2A cells. CREB is activated by phosphorylation of Ser-133 not only by PKA but also by CaMK and MAPK, so inhibition of any of these enzymes may lead to attenuation of $\mathrm{CRH}$ activity. In fact, chlorpromazine and other phenothiazine derivatives are recognized calmodulin antagonists and clozapine has been found to reduce ERK1/2-MAPK (Pozzi et al, 2003; Ratnakar et al, 1995). These kinases may play a role in the mechanism of action of those antipsychotics which inhibit their activity, for example, clozapine, chlorpromazine, but not in the mechanism underlying the action of other drugs which enhance ERK-MAPK or CaMK activity (Ninan et al, 2003; Pozzi et al, 2003; Yang et al, 2004). Moreover, the lack of chlorpromazine and clozapine effect on phospho-Ser-133-CREB level rather excluded their action via this pathway. If inhibition of $\mathrm{CRH}$ gene activity by some antipsychotics is connected with their action on CaMK or MAPK, another DNA-responsive element than CRE seems to be affected. Activators of CaMK and MAPK are unavailable, but PKC activator TPA, which is known to increase phosphorylation of ERK-MAPK (Schonwasser et al, 1998), partially attenuated the inhibitory effect of clozapine on CRH-CAT activity. Additionally, in the present study, clozapine has been found to decrease the activity of PKC. Therefore, besides activation of Akt, it is possible that this drug attenuated CRH gene activity also by inhibition of PKC and possibly in consequence the ERK-MAPK activity. Direct action of PKC on CRH gene activity in Neuro-2A cells is rather unlikely, since absence of a TPA-responsive element in the proximal $0.9-\mathrm{kb} 5^{\prime}$ flanking the hCRH gene has been reported (Vamvakopoulos and Chrousos, 1994).

In conclusion, the present data indicate that some antipsychotic drugs are able to inhibit basal and, to a lesser extent, the forskolin-induced $\mathrm{CRH}$ gene promoter activity. It may be a molecular mechanism responsible for their inhibitory action on HPA axis activity. Inhibition of $\mathrm{CRH}$ activity by clozapine and chlorpromazine results mainly from activation of PI3-K/Akt pathway. However, an involvement of CaMK and ERK-MAPK in the effects of some antipsychotic drugs on $\mathrm{CRH}$ gene activity is also possible.

\section{ACKNOWLEDGEMENTS}

We are grateful to Dr Anna Brillowska-Dąbrowska and Dr Sławomir Dąbrowski for hCRHCAT plasmid synthesis. We thank Ms B Korzeniak for her skillful technical assistance.

\section{REFERENCES}

Aimoto T, Kaida M, Numazaki K, Masuda Y, Murata T (1981). Development of tolerance to the stimulatory effect of neuroleptic butyrophenones on pituitary-adrenal activity in rats. J Pharmacobiodyn 4: 827-832.

Altamura AC, Boin F, Maes M (1999). HPA axis and cytokines dysregulation in schizophrenia: potential implications for the antipsychotic treatment. Eur Neuropsychopharmacol 10: 1-4.

Austin MC, Rhodes JL, Lewis DA (1997). Differential distribution of corticotropin-releasing hormone immunoreactive axons in monoaminergic nuclei of the human brainstem. Neuropsychopharmacology 17: 326-341.

Basta-Kaim A, Budziszewska B, Jaworska-Feil L, Tetich M, Kubera M, Leśkiewicz M et al (2005). Inhibitory effect of imipramine on the human corticotropin-releasing-hormone gene promoter activity operates through a PI3-K/AKT mediated pathway. Neuropharmacology 49: 156-164.

Basta-Kaim A, Budziszewska B, Jaworska-Feil L, Tetich M, Leśkiewicz M, Kubera M et al (2002). Chlorpromazine inhibits the glucocorticoid receptor-mediated gene transcription in a calcium dependent manner. Neuropharmacology 43: 1035-1043.

Binda AV, Kabbani N, Lin R, Levenson R (2002). D2 and D3 dopamine receptor cell surface localization mediated by interaction with protein 4.1N. Mol Pharmacol 62: 507-513.

Bloch M, Gur E, Shalev A (1994). Chlorpromazine prophylaxis of steroid-induced psychosis. Gen Hosp Psychiatry 16: 42-44.

Budziszewska B, Jaworska-Feil L, Kajta M, Lasoñ W (2000). Antidepressant drugs inhibit glucocorticoid receptor-mediated gene transcription - a possible mechanism. Brit J Pharmacol 130: $1385-1393$.

Budziszewska B, Jaworska-Feil L, Tetich M, Basta-Kaim A, Kubera M, Leśkiewicz M et al (2002). Effect of antidepressant drugs on the human corticotropin-releasing-hormone gene promoter activity in neuro-2A cells. Pol J Pharmacol 54: 711-716.

Budziszewska B, Jaworska-Feil L, Tetich M, Basta-Kaim A, Kubera M, Leśkiewicz M et al (2004). Regulation of the human corticotropin-releasing-hormone gene promoter activity by antidepressant drugs in Neuro-2A and AtT-20 cells. Neuropsychopharmacology 29: 785-794.

Chalecka-Franaszek E, Chuang DM (1999). Lithium activates the serine/threonine kinase Akt-1 and suppresses glutamate-induced inhibition of Akt-1 activity in neurons. Proc Natl Acad Sci USA 96: $8745-8750$.

Chan MY, Holmes WN (1978). The effect of some centrally active drugs on corticosterone secretion and metabolism in rats. Clin Exp Pharmacol Physiol 5: 641-647.

Chatterjee D, Chakraborty M, Anderson GM (1992). Differentiation of Neuro-2a neuroblastoma cells by an antibody to GM3 ganglioside. Brain Res 583: 31-44.

De Sarno P, Li X, Jope RS (2002). Regulation of Akt and glycogen synthase kinase-3 beta phosphorylation by sodium valproate and lithium. Neuropharmacology 43: 1158-1164.

Dirks A, Groenink L, Schipholt MI, van der Gugten J, Hijzen TH, Geyer MA et al (2002). Reduced startle reactivity and plasticity in transgenic mice overexpressing corticotropin-releasing hormone. Biol Psychiatry 51: 583-590.

Donati RJ, Thukral C, Rasenick MM (2001). Chronic treatment of C6 glioma cells with antidepressant drugs results in a redistribution of Gs $\alpha$. Mol Pharmacol 59: 1426-1432.

Durany N, Thome J (2004). Neurotrophic factors and the pathophysiology of schizophrenic psychoses. Eur Psychiatry 19: 326-337.

Dwivedi Y, Pandey GN (1999). Effects of treatment with haloperidol, chlorpromazine, and clozapine on protein kinase $\mathrm{C}$ (PKC) and phosphoinositide-specific phospholipase C (PI-PLC) activity and on mRNA and protein expression of PKC and PLC isozymes in rat brain. J Pharmacol Exp Ther 291: 688-704. 
Dwivedi Y, Rizavi HS, Pandey GN (2002). Differential effects of haloperidol and clozapine on $[3 \mathrm{H}] \mathrm{cAMP}$ binding, protein kinase A (PKA) activity, and mRNA and protein expression of selective regulatory and catalytic subunit isoforms of PKA in rat brain. J Pharmacol Exp Ther 301: 197-209.

Emamian ES, Hall D, Birnbaum MJ, Karayiorgou M, Gogos JA (2004). Convergent evidence for impaired AKT1-GSK3 $\beta$ signaling in schizophrenia. Nat Genet 36: 131-137.

Fiol CJ, Williams JS, Chou CH, Wang QM, Roach PJ, Andrisani OM (1994). A secondary phosphorylation of CREB341 at Ser129 is required for the cAMP-mediated control of gene expression. A role for glycogen synthase kinase-3 in the control of gene expression. J Biol Chem 269: 32187-32193.

Forman SD, Bissette G, Yao J, Nemeroff CB, van Kammen DP (1994). Cerebrospinal fluid corticotropin-releasing factor increases following haloperidol withdrawal in chronic schizophrenia. Schizophr Res 12: 43-51.

Guardiola-Diaz HM, Boswell C, Seasholtz AF (1994). The cAMPresponsive element in the corticotropin-releasing hormone gene mediates transcriptional regulation by depolarization. J Biol Chem 269: 14784-14791.

Gudelsky GA, Berry SA, Meltzer HY (1989a). Actions of typical and atypical antipsychotics on tuberoinfundibular dopamine neurons. Psychopharmacol Bull 25: 377-382.

Gudelsky GA, Nash JF (1992). Neuroendocrinological and neurochemical effects of sigma ligands. Neuropharmacology 31: 157-162.

Gudelsky GA, Nash JF, Berry SA, Meltzer HY (1989b). Basic biology of clozapine: electrophysiological and neuroendocrinological studies. Psychopharmacology (Berl) 99(Suppl): S13-S17.

Hung F, Chan MY (1981). The effect of long-term chlorpromazine and desipramine treatment on adrenal corticosterone, cyclic AMP, and cholesterol distribution in rats. Clin Exp Pharmacol Physiol 8: 567-574.

Kahn RS, Siever L, Davidson M, Greenwald C, Moore C (1993). Haloperidol and clozapine treatment and their effect on $\mathrm{M}$ chlorophenylpiperazine-mediated responses in schizophrenia: implications for the mechanism of action of clozapine. Psychopharmacology (Berl) 112(1 Suppl): S90-S94.

Karege F, Schwald M, El Kouaissi R (2004). Drug-induced decrease of protein kinase a activity reveals alteration in BDNF expression of bipolar affective disorder. Neuropsychopharmacology 29: 805-812.

Keim KL, Sigg EB (1977). Plasma corticosterone and brain catecholamines in stress: effect of psychotropic drugs. Pharmacol Biochem Behav 6: 79-85.

Klebe RJ, Ruddle FH (1969). Neuroblastoma: cell culture analysis of a differentiating stem cell system. J Cell Biol 43: 69.

Kozlovsky N, Belmaker RH, Agam G (2002). GSK-3 and the neurodevelopmental hypothesis of schizophrenia. Eur Neuropsychopharmacol 12: 13-25.

Lai M, McCormick JA, Chapman KE, Kelly PAT, Seckl JR, Yau JLW (2003). Differential regulation of corticosteroid receptors by monoamine neurotransmitters and antidepressant drugs in primary hippocampal culture. Neuroscience 118: 975-984.

Lammers CH, Garcia-Borreguero D, Schmider J, Gotthard U, Dettling M, Holsboer F et al (1995). Combined dexamethasone/ corticotropin-releasing hormone test in patients with schizophrenia and in normal controls: II. Biol Psychiatry 38: 803-807.

Legradi G, Holzer D, Kapcala LP, Lechan RM (1997). Glucocorticoids inhibit stress-induced phosphorylation of CREB in corticotropin-releasing hormone neurons of the hypothalamic paraventricular nucleus. Neuroendocrinology 66: 86-97.

Ling MH, Perry PJ, Tsuang MT (1981). Side effects of corticosteroid therapy. Psychiatric aspects. Arch Gen Psychiatry 38: 471-477.
Lowry OH, Rosenbrough NJ, Farr AL, Randall RJ (1951). Protein measurement with the Folin phenol reagent. J Biol Chem 193: 265-275.

Lu XH, Bradley RJ, Dwyer DS (2004). Olanzapine produces trophic effects in vitro and stimulates phosphorylation of Akt/PKB, ERK1/2, and the mitogen-activated protein kinase p38. Brain Res 1011: 58-68.

Marinelli M, Piazza PV, Deroche V, Maccari S, Le Moal M, Simon H (1994). Corticosterone circadian secretion differentially facilitates dopamine-mediated psychomotor effect of cocaine and morphine. J Neuroscience 14: 2724-2731.

Marinelli M, Rouge-Pont F, Deroche V, Barrot M, De Jesus-Oliveira C, Le Moal M et al (1997). Glucocorticoids and behavioral effects of psychostimulants. I: Locomotor response to cocaine depends on basal levels of glucocorticoids. J Pharmacol Exp Ther 281: 1392-1400.

McEwen BS, Magarinos AM (2001). Stress and hippocampal plasticity: implications for the pathophysiology of affective disorders. Hum Psychopharmacol 16: S7-S19.

Meltzer HY (1995). Dopamine, serotonin and glucorticoids and the psychopathology of schizophrenia. In: Fog R, Gerlach J (eds). Schizophrenia. Alfred Bunsen Symposium 38, Munksgaard, Copenhagen. pp 74-91.

Monsma Jr FJ, Brassard DL, Sibley DR (1989). Identification and characterization of D1 and D2 dopamine receptors in cultured neuroblastoma and retinoblastoma clonal cell lines. Brain Res 492: 314-324.

Newcomer JW, Faustman WO, Whiteford HA, Moses Jr JA, Csernansky JG (1991). Symptomatology and cognitive impairment associate independently with post-dexamethasone cortisol concentrations in unmedicated schizophrenic patients. Biol Psychiatry 29: 855-864.

Nikodemova M, Kasckow J, Liu H, Manganiello V, Aguilera G (2003). Cyclic adenosine $3^{\prime}, 5^{\prime}$-monophosphate regulation of corticotropin-releasing hormone promoter activity in AtT-20 cells and in a transformed hypothalamic cell line. Endocrinology 144: $1292-1300$.

Ninan I, Jardemark KE, Liang X, Wang RY (2003). Calcium/ calmodulin-dependent kinase II is involved in the facilitating effect of clozapine on NMDA- and electrically evoked responses in the medial prefrontal cortical pyramidal cells. Synapse 47: 285-294.

Pariante CM, Pearce BD, Pisell TL, Owens MJ, Miller AH (1997). Steroid-independent translocation of the glucocorticoid receptor by the antidepressant desipramine. Mol Pharmacol 52: 571-581.

Peruche B, Krieglstein J (1991). Neuroblastoma cells for testing neuroprotective drug effects. J Pharmacol Methods 26: 139-148.

Piazza PV, Rouge-Pont F, Deroche V, Maccari S, Simon H, Le Moal M (1996). Glucocorticoids have state-dependent stimulant effects on the mesencephalic dopaminergic transmission. Proc Natl Acad Sci USA 93: 8716-8720.

Post A, Holsboer F, Behl C (1998). Induction of NF-kappaB activity during haloperidol-induced oxidative toxicity in clonal hippocampal cells: suppression of NF-kappaB and neuroprotection by antioxidants. J Neurosci 18: 8236-8246.

Pozzi L, Hakansson K, Usiello A, Borgkvist A, Lindskog $M$, Greengard P et al (2003). Opposite regulation by typical and atypical anti-psychotics of ERK1/2, CREB and Elk-1 phosphorylation in mouse dorsal striatum. J Neurochem 86: 451-459.

Ratnakar P, Rao SP, Sriramarao P, Murthy PS (1995). Structureantitubercular activity relationship of phenothiazine-type calmodulin antagonists. Int Clin Psychopharmacol 10: 39-43.

Ryan MC, Flanagan S, Kinsella U, Keeling F, Thakore JH (2004). The effects of atypical antipsychotics on visceral fat distribution in first episode, drug-naive patients with schizophrenia. Life Sci 74: 1999-2008.

Schonwasser DC, Marais RM, Marshall CJ, Parker PJ (1998). Activation of the mitogen-activated protein kinase/extracellular 
signal-regulated kinase pathway by conventional, novel, and atypical protein kinase C isotypes. Mol Cell Biol 18: 790-798.

Seasholtz AF, Thompson RC, Douglass JO (1988). Identification of a cyclic adenosine monophosphate-responsive element in the rat corticotropin-releasing hormone gene. Mol Endocrinol 2: 1311-1319.

Smith CL, Wolford RG, O’Neill TB, Hager GL (2000). Characterization of transiently and constitutively expressed progesterone receptors: evidence for two functional states. Mol Endocrinol 14: 956-971.

Spengler D, Rupprecht R, Van LP, Holsboer F (1992). Identification and characterization of a $3^{\prime}, 5^{\prime}$-cyclic adenosine monophosphate-responsive element in the human corticotropinreleasing hormone gene promoter. Mol Endocrinol 6: 1931-1941.

Sweep CG, Boersma CJ, Wiegant VM (1990). Effects of chronic treatment with haloperidol and bromocriptine on the processing of beta-endorphin to gamma- and alpha-endorphin in discrete regions of the rat pituitary gland and brain. Neuropharmacology 29: 61-68.

Tandon R, Mazzara C, DeQuardo J, Craig KA, Meador-Woodruff JH, Goldman R et al (1991). Dexamethasone suppression test in schizophrenia: relationship to symptomatology, ventricular enlargement, and outcome. Biol Psychiatry 29: 953-964.

Tyson DR, Swarthout JT, Jefcoat SC, Partridge NC (2002). PTH induction of transcriptional activity of the cAMP response element-binding protein requires the serine 129 site and glycogen synthase kinase-3 activity, but not casein kinase II sites. Endocrinology 143: 674-682.

Vamvakopoulos NC, Chrousos GP (1994). Hormonal regulation of human corticotropin-releasing hormone gene expression: implications for the stress response and immune/inflammatory reaction. Endocrine Rev 15: 409-420.

Webster MJ, Knable MB, O'Grady J, Orthmann J, Weickert CS (2002). Regional specificity of brain glucocorticoid receptor mRNA alterations in subjects with schizophrenia and mood disorders. Mol Psychiatry 7: 985-994.

Wik G, Wiesel FA, Eneroth P, Sedvall G, Astrom G (1986). Dexamethasone suppression test in schizophrenic patients before and during neuroleptic treatment. Acta Psychiat Scand 74: 161-167.

Yamamori E, Asai M, Yoshida M, Takano K, Itoi K, Oiso Y et al (2004). Calcium/calmodulin kinase IV pathway is involved in the transcriptional regulation of the corticotropin-releasing hormone gene promoter in neuronal cells. J Mol Endocrinol 33: 639-649.

Yang BH, Son H, Kim SH, Nam JH, Choi JH, Lee JS (2004). Phosphorylation of ERK and CREB in cultured hippocampal neurons after haloperidol and risperidone administration. Psychiatry Clin Neurosci 58: 262-267.

Zhu D, Jiang X, Wu X, Tian F, Mearow K, Lipsky RH et al (2004). Inhibition of protein kinase $C$ promotes neuronal survival in low potassium through an Akt-dependent pathway. Neurotox Res 6: 281-289. 